\author{
Чень Юньцзя, \\ аспірантка Національної музичної академії \\ України імені П. І. Чайковського \\ ORCID 0000-0002-0362-7912 \\ chengyunjia@hotmail.com
}

\title{
ОСОБЛИВОСТІ ПРОГРАМНОГО СИМФОНІЗМУ 1990-х РОКІВ У СУЧАСНІЙ КИТАЙСЬКІЙ КОМПОЗИТОРСЬКІЙ ТРАДИЦЇ̈ НА ПРИКЛАДІ «П'ЯТИ СТИХІЙ» (“WU XING", “LES CINQ ÉLÉMENTS") ДЛЯ СИМФОНІЧНОГО ОРКЕСТРУ ЦИГАНА ЧЕНЯ
}

\begin{abstract}
Мета роботи. Стаття має на меті виведення системних рис програмного симфонізму, як методу художнього мислення та національних особливостей китайської симфонічної музики для європейського оркестру. Методологія дослідження полягає у використанні цілісного, системного, порівняльного та історичного методів музикознавчого аналізу. Наукова новизна роботи полягає в тому, що автор вперше впроваджує до вітчизняного наукового обігу твір, що належить до царини китайського програмного симфонізму та визначає ступінь трансформації національної традиції та новаторства музичного стилю Цигана Ченя. Висновки. «П’ять стихій» Цигана Ченя - це яскравий зразок китайського програмного симфонізму 1990 $\mathrm{x}$ років, виявами якого стають циклічність, методи розробки і поліфонічний тип розвитку у достатньо невеликому форматі, звукозображальність і характерні підходи в оркеструванні, звернення до тембрів китайських народних інструментів флейти і ерху, поемність, концертність, стильові алюзії до епохи бароко через звернення до риторичних фігур як носіїв підвищеного емоційного впливу музики на слухача, вільне використання сучасних композиторських технік і розмиття поняття «тональність» $\mathrm{i}$ «теорія функцій» у звичній класично-романтичній системі.
\end{abstract}

Ключові слова: програмний симфонізм; монотематизм; принцип концертності; принцип ізометричного мотету; лейтобраз-«баранчиків» хвиль на воді; репризність; риторична фігура passus duriusculus; кластерність.

Чень Юньцзя, аспирантка Национальной музыкальной академии Украины имени П. И. Чайковского

Особенности программного симфонизма 1990-х годов в современной китайской композиторской традиции на примере «Пяти стихий» (“Wu Xing”, “Les Cinq Éléments”) Цигана Чэня для симфонического оркестра

Цель работы. Целью статьи является выведение системных черт программного симфонизма, как метода художественного мышления и национальных особенностей китайской симфонической музыки для европейского оркестра. Методология исследования заключается в использовании целостного, системного, сравнительного и исторического методов музыковедческого анализа. Научная новизна работы заключается в том, что автор впервые внедряет в отечественный научный оборот произведение, принадлежащее наследию китайского программного симфонизма, и определяет степень трансформации национальной традиции и новаторства музыкального стиля Цигана Чэня. Выводы. «Пять стихий» Цыгана Чэня - это яркий образец китайского программного симфонизма 1990-х годов, проявлениями которого становятся цикличность, методы разработки и полифонический тип развития в достаточно небольшом формате, звукоизобразительность и характерные прийомы в оркестровке, обращение к тембрам китайских народных инструментов флейты и эрху, поемность, концертность, стилевые аллюзии к эпохе барокко через обращение к риторическим фигурам как носителям повышенного эмоционального воздействия музыки на слушателя, свободное использование современных композиторских техник и размытие понятия «тональность» и «теория функций» в привычной классико-романтической системе.

Ключевые слова: программный симфонизм; монотематизм; принцип концертности; принцип изометрического мотета; лейтобраз-«барашков» волн на воде; репризность; риторическая фигура passus duriusculus; кластерность.

Cheng Yunjia, postgraduate of the National Music Academy of Ukraine by P. I. Tchaikovsky

Particularities of program symphonic style of the 1990s in the contemporary Chinese composing tradition, case study: "Wu Xing" ("Les Cinq Éléments") for Qigang Chen's symphonic orchestra

Purpose of the article. This article has the purpose of outlining systemic features of symphonic program style as a method of artistic thinking and national particularities of Chinese symphonic music for a European orchestra. The methodology envisages the use of the holistic, systematic, comparative, and historical methods of musical analysis. The scientific novelty of research results stems from the fact that the author is the first scholar who introduced to Ukrainian scientific overview a work from the realm of Chinese program symphonic style and defined the degree of transformation of national tradition and innovativeness of Qigang Chen's music style. Conclusions. Qigang Chen's

()Чень Юньцзя, 2019 
"Les Cinq Éléments" is a vivid example of Chinese program symphonic style of the 1990s, which manifests itself in cyclicality, conception methods and polyphonic type of development in a quite small format, audiovisual nature and characteristic approaches in orchestration, addressing the timbres of Chinese folk instruments flute and erhu, poem principle, concert principle, style allusions with the baroque era by addressing rhetoric figures as the carriers of heightened emotional effect of music on the listener, free use of modern composing techniques, and dilution of the notions of "tonality" and "theory of functions" in the regular classical romantic system.

Key words: symphonic program style; monothematic technique; concert principle; isometric motet principle; legitimate of wave "whitecaps"; repriseness; rhetoric figure passus duriusculus; clustering.

Актуальність теми дослідження. У межах пропонованої статті простежимо характер прояву програмного симфонізму з точки зору інноваційного підходу сучасного китайського композитора Цигана Ченя - залученням переосмислених національних елементів до стильових ознак різних епох як посмодерністичних виявів, європейських сучасних композиторських технік письма, підвищеної складності і віртуозних можливостей виконавського мистецтва за для створення відособленої ультрасучасної авторської композиції межі XX-XXI століть.

Аналіз досліджень і публікацій. Нині у китайському музикознавці спостерігаємо активний інтерес до жанрового спектру китайської академічної музики. Питанню виникнення і розвитку китайської симфонічної музики присвячено чимало робіт, але в них здебільшого немає поглибленого і спеціального вивчення цієї теми (роботи Ло Шиі [2], Лі Ланьцина [1], Лян Маочуня [3]). Проблема «програмний симфонізм у творчості сучасних китайських композиторів 1990-х років» ще не отримала належного наукового осмислення, чим пояснюється актуальність пропонованої теми.

Мета дослідження - виведення, крізь аналіз композиційно-драматургічної побудови твору, системних рис програмного симфонізму, як методу художнього мислення та, зокрема, національних особливостей китайської симфонічної музики для європейського оркестру.

Виклад основного матеріалу. У творчості «імператора китайської сучасної музики» [9], випускника Пекінської та Паризької консерваторій Цигана Ченя, представлена симфонічна, вокально-хорова, камерно-інструментальна музика програмного характеру як для класичних, так і для традиційних китайських інструментів (оркестрів), жанр концерту для інструменту соло 3 оркестром; електронна музика, музика до балету, музика до кінофільмів та естрадні пісні. Серед рис стилю М.-Е. Бернар відзначає приналежність до постмодернізму, що відповідає потребам сучасної музики - знаходження власного «Я» композитором у бездні історичних музичних стилів. Звернення до китайського фольклору, характерних мелодій у рамках постмодернізму отримує «сильний ностальгічний вимір» [7].

«П’ять стихій» (“Wu Xing”, “Les Cinq Éléments”) для симфонічного оркестру (1999) створювався на замовлення Міжнародного французького радіо. Аудіозапис прем’єри твору здійснений 21 травня 1999 року Національним симфонічним оркестром Франції, а 10 лютого 2018 року цим же колективом створений відеозапис твору на концерті Паризької філармонії. Окрім цих двох інтерпретацій (із проміжком часу в 19 років від першого виконання), згідно із авторським сайтом Цигана Ченя, «П'ять стихій» за останні неповні шість років (з 2014 по 2019 роки) було виконано 19 оркестрами світу [10].

У творі автор звертається до основного напрямку в китайській філософії- вчення «Тайцзи» («Велика Межа»), що «означає найвищий ступінь характеристики філософського осмислення буття людини і природи. < ..> На старокитайській мові веньянь слово “Тайцзи” означає “центр космосу”. На сучасній мові “Тайцзи” - це “Річ, яка існує в гармонійному русі”» [4, 7]. Вчення «Тайцзи» стало джерелом виникнення старокитайської філософії Лао-цзи «Дао» та основою конфуціанства. Подальший його розвиток пов'язаний із ім'ям китайських філософів Дун Чжуншу і Чжу Сі. Давньокитайський філософ Чжуан-цзи видав трактат під назвою «Чжуан-цзи», в якому розкрив міфологічну модель архетипу «Усин» («П'ять стихій») - однієї 3 основних категорій китайської філософії, що позначає універсальну класифікаційну схему, згідно якої всі основні параметри світобудови мають п'ятичленну структуру. «П'ять стихій» включали в себе «воду», «вогонь», «землю» («грунт»), «дерево», «метал» [там само]. Останні дві стихії вписано у світові процеси, тому людину розглядають як органічну частину Космосу. Ці елементи співпрацюють разом: деревина створює вогонь, вогонь - землю, земля - метал, метал - воду, а вода - дерево.

Сюїта, як друге авторське жанрове визначення, є втіленням грандіозної ідеї Олів'є Мессіана (викладача Цигана Ченя) про ідеальне злиття східної філософської емоції та західної музичної виразності. «П'ять стихій» представляють динамічний процес: робота стосується не традиційних фізичних речовин, а циклічних рухів, які, згідно з традиційною китайською концепцією, становлять Всесвіт. Композитор висловлює таким чином своє особисте бачення зв'язків між цими елементами, пропонує музичну інтерпретацію того, що кожен елемент символізує для нього, і викладає новий порядок викладу п'яти елементів, заснований на генеруючій функції: Вода-Дерево-Вогонь-Земля-Метал [8]. 
Партитурна система твору - великий симфонічний оркестр із потрійним складом дерев'яних духових інструментів, розширеною групою ударних, що поділяється композитором на 4 підгрупи (кожна 3 яких має свій нотоносець і виконується лише одним музикантом), арфою, фортепіано та челестою.

Перша частина «Вода» (“Shui”, “L’eau”) $\boldsymbol{J}=42$ укладається композитором за хронометражним принципом (часто застосовуваним у кіномузиці) у 2 хвилини і 3 секунди, 29 тактів партитури та однотемну двочастинну форму (перша частина - 13 тактів, друга - 16). У вступних чотирьох тактах за імітаційним принципом вступають партії струнної групи, бас-кларнету і кларнету in Es, тромбону, маримби (2 і 3 групи ударних), вібрафону, там-таму, арфи і челести. Партії кларнетів, тромбону й маримби за образною і програмною асоціацією відображують «баранчики» хвиль на воді технічними засобами контрольованої алеаторики, побудованої на звуках пентатоніки розширеного $C$-dur 3 iї інваріантами від різних тонів. Партії ксилофону, арфи і челести окремими звуками, вирішеними у октавних martellato на $p p$ та ритмічно подрібненими довжинами. Прозорість водяної гладі підкреслюють окремі тони пентатоніки $C$-dur у струнних $\left(\mathrm{C}, \mathrm{D}, \mathrm{g}, \mathrm{a}^{1}-\mathrm{a}^{2}, \mathrm{e}^{3}-\mathrm{g}\right)$, виконаних флажолетами. Останній тон е $\mathrm{e}^{3}$ у альта ще й виконується висхідним glissando (прийом «якомога вище»-“as high as possible”). У 2 такті композитором закладений і хроматичний варіант теми ("g-a-fis-b-f-a-fis-b-gis-a-g-a-fis-g”), який оновиться у наступному матеріалі частини.

Такти 5-13 - друга хвиля розвитку тематизму експозиції. Автор зберігає принцип діалогу діатонічними поспівками-«баранчиками» хвиль на воді у партіях маримби (2 і 3 груп), ксилофона, Glockenspiel, фортепіано i флейти piccolo, 2-ї флейти, 2-го кларнета, 3-го фагота квінтолями шістнадцятими і 1 тромбона децимолями шістнадцятими з флажолетами і висхідними glissando струнних. Однак з появою ще одного зигзагоподібного хроматичного варіанту розширеного $C$-dur у арфи ("cis-

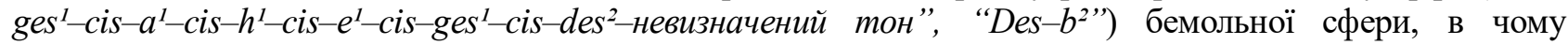
вбачаємо деяку конфліктність. У партії 1-ї флейти і 1-го кларнета додається гра 3 «мерехтінням» перекресленого форшлагового тону “ais-a” до " $h$ ” (що образно підкріплює образ деренчливого відбиття сонячного світла у воді) та новий технічний прийом - (slow vibrato). У 9-10 тактах «мерехтіння» форшлагового тону інтонаційно замінюється на " $g$ - $a$ ” до “ $b$ ” у соло 1-ї віолончелі. У тих же 9-10 тактах у партіях 1-3 кларнету і 1-3 тромбонів утворюється бемольний варіант III'5 ("ges-b-des$e s ”)$ на тремоло, як противага - у валторн: діатонічні терцієво-секундові чотирьох звучні кластери на тремоло, що складаються із тонів основної тональності експозиційного розділу та у маримби (2 і 3 груп) хроматичні терцієво-секундові чотирьох звучні кластери на тремоло з єдиним новим тоном "es”.

Друга частина однотемної двочастинної форми (тт. 14-29) доволі вільна та імпровізаційна, віртуозна для виконавців завдяки зверненню до сучасної техніки письма - фактурно-обмеженої алеаторіки. Зокрема, у першому періоді (тт. 15-22) в усіх партіях дерев'яних- і мідно-духових інструментів за основу беруться децимолі, 12-ти і 14-ти звучні пентатонічні групи шістнадцятими 3 експозиційного розділу твору, котрі тепер подрібнюються як ритмічно (64-ті), так і метрично (на секстолі, септолі, октолі, новемолі), а також поєднують у собі діатонічні і хроматичні тони. До високо-технічної складності виконання фактурно-обмеженої алеаторики додаються нові прийоми гри - трелі, широка динамічна градація, як музичне відображення програмного образу води - стихії зароджуваної морської бурі, розкачування високих хвиль. Тому ж сприяють і принципи симфонічного розвитку тематизму концертуючі протиставлення груп оркестру: духових струнним з ударними. Якщо у перших переважно пасажна техніка із комбінаціями окремих мелодичних тонів, то у других (як першоджерелом, витоком морської хвилі) - акордова фактура, звуки якої складається із попередніх інваріантів початкової мелодії.

Другий період однотемної двочастинної форми (тт. 20-29) розпочинається з другої хвилі розвитку. Так, акордова фактура струнних у тт. 21-24 вперше за увесь твір сформувала не просто нашарування окремих звуків пентатоніки та іiі інваріантів, а Д7 з підвищеними 1,3 і 5 щаблями, як складову кадансового звороту, на фоні звуків якого далі розпорошено звучатиме двотактовий діатонічний епізод фактурно-обмеженої алеаторики у партіях 1-ї скрипки, альтів i віолончелей. Таке схрещення функціональної гармонії із лінеарністю створює шумовий ефект, або образ розбиття хвиль об скали. Паралельно із цим дисонантним звучанням як ще один пласт оркестрової партитури генерується діатонічний острівець фактурно-обмеженої алеаторики (тт. 24-29) у духових і челести, котрий повертає розвиток тематизму до початкових експозиційних варіантів теми.

Друга частина «Дерево» (“Mu”, "Le Bois”) J = 60 відкривається однотактовою зв'язкою, корені якої сягають тематизму першої частини (16-тизвучного елементу 64-ми у 6 Wood-bloks, т. 25), але поліритмічно викладений у декількох варіантах у 6 Wood-bloks 2-ї (дві новемолі 64-ми) і 4-ї груп ударних (дві децимолі 64-ми) та 6 Temple-blocks 1-ї (дві децимолі 64-ми) і 3-ї груп ударних (ніби оголошуючи своїм тембральним звучанням початок «панування» нової стихії- дерева) та вміщений у періодичний 
перемінний розмір 2/4+1/8. Цікаво, що Циган Чень і надалі буде звертатися до перемінного розміру впродовж частини, дзеркально зупиняючись на першому. Із попередньою частиною пов'язують і епізодизв'язки - висхідні пасажі арфи, фортепіано, ксилофона і маримби (трансформований лейтобраз «баранчиків» хвиль на воді).

Обсяг частини - 32 такти. За тематизмом - одночастинна наскрізна музична форма, насичена звукозображальними елементами, градаціями динамічного звучання, поліритмічних напластувань (у т. 19; т. 20-22 за принципом ізометричного мотету) та сучасною композиторською технікою. Зокрема, фактурно-обмеженою (контрольованою) алеаторикою: тт. 11-12 у всього оркестру, де у груп дерев'яних і мідних духових та ударних інструментів виписані регістр і динаміка мелодичного малюнку, діапазон звучання, то у струнних вказані лише векторна направленість гри: «грати по черзі на кожній струні»/“"play alternately on eash string" та пояснення як грати «Не соромтеся зрушувати ряд між мостом краю борту» /"Feel free to shift the row between the bridge edge of the fingerboard and the 1.k.". Останній прийом застосується на останніх 7 тактах частини, де композитор розділить партії скрипок і альтів на підпартії та запропонує грати на окремих струнах (струни “ $a$ ", “ $d$ ” i “e”).

Третя частина «Вогонь» (“Нuo", "Le feu”) $\boldsymbol{d}^{\prime}=60$, як і попередня, невелика за обсягом - 32 такти і за часом звучання - 2 хвилини 7 секунд. Також із «Деревом» частину споріднює наскрізна форма, побудована на монотематизмі та концертному діалозі окремих груп оркестру і сольних інструментальних епізодів (тт. 24-30 bass drum). Споріднюючим фактором є перемінний розмір.

Функцію гармонічного остову виконує група мідних духових інструментів, арфи і фортепіано. Окрім тембрального і ритмічного контрасту, музична тканина являє собою поліфонічну фактуру 3 поступовим розгортанням матеріалу. Протягом лінеарного розвитку виникли такі фонічні співзвуччя:

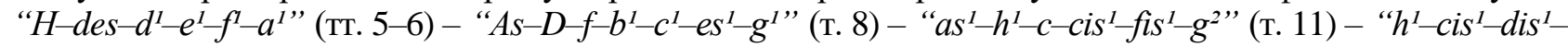

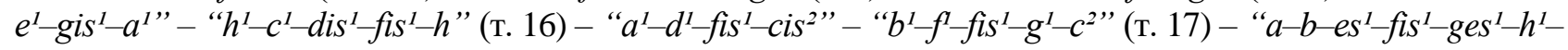

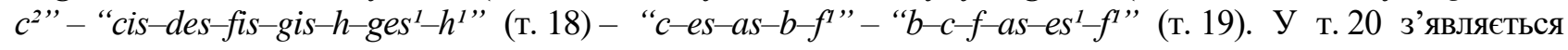
проміжна тоніка - великий мажорний септакорд " $B-d e s-g e s-b-f^{\prime}$ ”, а у т. 29-31- його енгармонічна версія-розв'язання у розгорнений Т ${ }^{53}$ Fis-dur "Fis-Cis-fis-ais-cis ${ }^{1}-$ fis $^{1}$ ".

Група мідних духових, арфи і фортепіано протиставлена групі дерев'яних духових (окрім партії кларнетів, фаготів і контрафаготу у тт. 11-12, 21-24 (без контрфаготу), струнних (окрім тт. 11-12II альт, віолончелі) і ударних інструментів (до маримби і ксилофону додаються Suspended cymbal, tamtam, Bass drum, виконуючи колористичну функцію - образ мерехтливих «язиків полум'я» за допомогою дрібних ритмічних груп: тріолі, квінтолі шістнадцятими, секстолі, септолі, децимолі 64-ми), хроматизації мелодичної лінії, переважно низхідного вектору руху, технічній складності для виконання. Поява висхідних і низхідних варіантів риторичної фігури passus duriusculus у парних звучаннях за тематизмом партій флейти і гобоя, 2-ї флейти і 2-го кларнета, 2-го гобоя (3-й варіант) (тт. 7-8) як звукопис вогню, потім розповсюджується і на інші голоси партитури, але як результат лінеарного руху голосів.

Четверта частина «Земля» (“Tu”, "La terre”) $\boldsymbol{J}=46$ Tranquillo найменша за обсягом (25 тактів) i оркестровою палітрою, найповільніша за темпом і стала за розміром протягом всієї композиції (4/4). Задля прозорості фактури і «легкості» звучання при філігранній складній техніці виконання, композитор прибирає зі складу партитури контрфагот, усі інструменти мідно-духової групи, розширює ударну групу - із зазвичай часто вживаними маримбами 2 і 3 груп ударних, ксилофоном, великим бас-барабаном, додає Glockenspiel (як у № 1 «Вода») і трикутник, а також доповнює групу клавішно-щипкових.

«Земля», як частина симфонічного циклу, має загальні риси із попередніми розділами сюїти: наскрізна розробкового типу музична форма, побудована на поліфонічних (імітаційність, підголосковість) і симфонічних (переінтонування, варіативність, репризність) прийомах розвитку тематизму, елементах концертності (сольні епізоди: флейти piccolo i 1-го альта у тт. 12-18, котрі, як відзначив у рецензії Лоуренс А. Джонсон "Chicago Classical Review" (2014), тембрально нагадують звучання китайських народних інструментів флейти і ерху [9] та стилізовані за тематизмом до фольклорної варіативності мелодії - ритмічної й інтонаційної; сольних дво- чи тритактових мотивів у 1-ї скрипки у тт. 2-3, 7-8, 1617, у 2-ї скрипки у тт. 8 і 16-17, у bass drum у тт. 19-20 (соло трелями, як у фінальних тактах № 3 «Вогонь»);

- у заключних тт. 20-25, як і у останніх7 тактах № 2 «Дерево», композитор звертається до прийому гри на окремих струнах та розділення на підгрупи групи струнних інструментів: гра на струні “ $a$ ”, “ $d$ ”, “e”. Обираються схожі виконавські складнощі - гра флажолетами із висхідними glissando у діапазоні від першої до четвертої октав. Додається лише прийом гри рикошетом на кульмінаційному тоні $h_{4}$, котрий $\epsilon$ довгоочікуваним консонансним розв'язанням диссонантного фонізму всієї частини; 
- заключні 5 тактів, як і у всіх попередніх частинах, вимальовують основний гармонічний тон лише наприкінці розвитку. У «Землі», як і у «Вогні» у музичній тканині представлений гармонічний остов (замість мідних духових - струнні, арфа, фортепіано) і колористика (дерев'яні духові, ударні). Гармонія частини формується так само і у попередніх розділах - лінеарно, звідси співіснування діатоніки $\mathrm{i}$ хроматики (дієзності та бемольності). Лише у тт. 21-25 формується гармонічна вертикаль шляхом лінеарного поліфонічного розвитку голосів: " $B-e s^{1}-a^{1}-e^{2}-f^{2}-e^{3}$ ” (т. 21) - “fis $-g i s^{1}-c^{2}-f^{2}-a^{2}-h^{2}-e^{3}$ ” (т. 22) “ $h$ "” (тт. 24-25);

- схожими є і технічні прийоми гри ударних: у ксилофона "slow motor speed"/«Повільна швидкість двигуна» - iз № 1 «Вода» (партії 1-го кларнета і фортепіано) та № 3 «Вогонь» (партія вібрафона, тт. 22-24), тремоло ударних і фортепіано у тт. 4-6, 9-10 із № 1 «Вода» та № 3 «Вогонь».

Фінальна п’ята частина «Метал» (“Jin”, “Le Métal”) $\delta=112$ найшвидша за темпом, найбільша за обсягом (53 такти) і наближена до середньої тривалості звучання частин циклу (2 хвилини). Композитор лишається вірним собі і у наявності перемінного розміру та розширенню складу оркестру за рахунок групи ударних. Iнтерес до Tubular bells (Chimes) пояснюємо фонічним відображенням програмностіколористичним звучанням інструментів металевого походження. Як і у попередній частині, партитура «Металу» включає в себе всі можливі клавішно-щипкові інструменти й тубу.

Фінальна частина акумулює всі характерні прийоми циклу, адже є кульмінаційним підсумком: гра на струні (“ $a$ ”, “e”, " $d$ ” (т. 4), далі у епізоді тт. 33-43, побудованому на тематизмі ізометричного епізоду (тт. 29-35, русі шістнадцятими, чергування тонів "cis ${ }^{l}$-dis ${ }^{l}$ ”) - струна " $g$ ” $\mathrm{i}$ " $d$ ".

- тематична паралель із № 2 «Дерево»: ізометричним епізодом струнних (тт. 20-22) у викладенні флейт, кларнетів і фаготів, мідних духових тільки не у розмірі $3 / 8$, шістнадцятими і секстово-терцієвою інтонаційною основою, а у 4/8, у поліритмічному поєднанні тріолей шістнадцятими і 64-ми 3 восьмими шістнадцятими нотами та м2-в2-м3 «виляннями» 3 поступовими виблискуваннями тонів висхідного і низхідного passus duriusculus.

-у т. 23 з'являються трелі у дерев'яних духових, що тематично відсилають слухача до такого ж прийому № 1 «Вода», а у тт. 25-28 лейттема «баранчиків» хвиль на воді з тієї ж першої п’єси, вирішена автором у техніці контрольованої алеаторики у партіях маримби (2 і 3 груп) і кларнету, тепер запропонована у хроматичному варіанті-чергуванні висхідних і низхідних риторичних фігур passus duriusculus у імітаційному викладенні в партіях 3-го кларнету, 2-го фаготу, 1-їтруби, арфи і фортепіано, 2ї скрипки і 1-ї віолончелі (тт. 26-28).

- «Метал», як і № 4 «Земля», має сольні звучання 1-ї скрипки (тт. 3-7, 13-14, 28-29), останнє навіть забарвлене характерним технічним прийомом висхідного glissando, а також партії фортепіано (тт. 11-12).

- тематична арка із № 1 «Вода»-діатонічних терцієво-секундових чотирьох звучних кластерів на тремоло у валторн і хроматичних терцієво-секундових чотирьох звучних кластерів на тремоло у маримби (2 і 3 груп) - у тт. 23-24 ч4-ч5-в2 хроматичний кластер на тремоло у ксилофона і маримби (2 і 3 групи), у тт. 26-28 тремоло в2 у ксилофона, у тт. 25-29 терцієво-секундовий чотирьох звучний кластер на тремоло у струнних прийомом sul ponticello, тт. 43-44 чергування терцієво-секундових чотирьох звучних хроматичних кластерів у фортепіано.

- підвищена технічна складність підкріплюється і авторськими ремарками щодо виконання, як наприклад: у партії tam-tam (т. 12) і suspended cymbal (тт. 30-31) "rub with a piece of metal"/«нamupaüme шматочком металу» (паралель із партією альта висхідним glissando № 1); у партіях струнних (тт. 20-25) "tutti as mush now as possible in the shortest time possoble"/«разом як можна більше за найкоротший час» та гра флажолетів; у партії валторни (тт. 13-14) графічно відображені чергування при грі закритих і відкритих звуків тощо.

Останні 12 тактів розпочинаються епізодом у флейт, гобоїв і кларнетів із поступовим імітаційним вступом голосів за ритмічною групою чотири 64-х залігованих із половинкою і половинкою через такт із двома вісімками, що далі підхоплюється мідним квінтетом і ударними поліфонічної фактури (3 протискладаннями за принципом ритмічного контрасту, тт. 43-45) і повторами висхідних і низхідних diгур passus duriusculus до поки у педалі органного пункту на тоні “c” у контрабасів (3 тт. 44-46) не опанує усі шари оркестрової партитури. Останній акорд - це фінальна фонічна крапка циклу " $C_{l}-C-h-b^{2}-$ $a i s^{3}-a^{3}-a s^{4}$, у якій як фатум, проглядається низхідна лінія passus duriusculus.

Висновки. Сучасний твір «П'ять стихій» Цигана Ченя акумулює в собі жанрові риси програмного симфонізму (циклічність, методи розробки і поліфонічний тип розвитку у достатньо невеликому форматі, звукозображальність і характерні підходи в оркеструванні, звернення до тембрів китайських народних інструментів флейти і ерху), поемності (монотематизм, лейтемності), концертності (концертний діалог окремих груп оркестру, сольні інструментальні епізоди), стильові алюзії до епохи бароко через звернення до риторичних фігур як носіїв підвищеного емоційного впливу музики на слухача (висхідних і низхідних 
варіантів passus duriusculus), вільне використання сучасних композиторських технік (фактурно-обмежена алеаторика) і розмиття поняття «тональність» і «теорія функцій» у звичній класично-романтичній системі: у творі головну роль відіграють сполучення між консонантними і диссонантними, діатонічними $\mathrm{i}$ хроматичними мелодичними сполуками, що модифікуються у процесі розвитку в діатонічно-хроматичні кластери та їх ускладнені хроматичні варіанти, котрі наприкінці кожної частини все ж таки отримують розв'язання у тимчасовий основний тон або співзвуччя (у № $1-$ розширений $C$-dur, у № $2-$ кластер " $b-c-$ $d i s-g-a s$ ”, у № 3 - розгорнений $\mathrm{T}_{3}^{5}$ Fis-dur, № 4 -основний тон “ $h$ ”, у № 5 - педаль основного тону “c” (тональною аркою до № 1) і акорд, побудований на низхідному passus duriusculus " $c-h-b$-ais-a-as"). Окремого значення набуває у творі професійна майстерність виконавця - скарбниця прийомів гри та зразок найсучаснішої музичної нотації з авторськими поясненнями правил виконання того чи іншого прийому на двох мовах: англійській і французькій.

\section{Лimepamypa}

1. Ли Ланьцин. Чжунго цзаоци цзяосян иньюэ [李岗清.中国早期的交响音乐]. Ранний этап развития китайской симфонической музыки // Размышления о современной китайской музыке: сб.ст./ Сост.: Ли Ланьцин. Пекин : Гаодэн цзяою чубаньшэ, 2008. - С. 23-32.

2. Ло Шии. Симфонические жанры в контексте китайской музыкальной культуры : автореф. дис. ... на соиск. науч. степ. канд. искусствоведения : спец. 17.00.02 / Ло Шии. - Москва : Российская Академия музыки имени Гнесиных, 2003. -21 с.

3. Лян Маочунь, Сян Сяоган, Ли Янь. Чжунго иньюэ луньбянь [梁茂春, 项篠刚, 李岩.中国音乐论辩]. Дискуссии о китайской музыке / Лян Маочунь, Сян Сяоган, Ли Янь. - Наньчан : Байхуачжоу ищу чубаньшэ, 2007. $438 \mathrm{c}$.

4. Хань Луцзяо. Философия «Тайцзи» как теоретическая основа развития искусства в Китае : автореф. дисс. на соиск. учен. степ. канд. искусствоведения : 17.00.09/ Хань Луцзяо. - Минск : Белорусский государственный университет культуры и искусств, 2017. - 27 с.

5. Циган Чень. Біографія / Чень Циган. URL: http://www.chenqigang.com/biography.php (дата звернення : 29.07.2019).

6. Chen Qigang/Cdmc. Centre de documentation de la musique contemporain. URL: http://www.cdmc.asso.fr/fr/ressources/compositeurs/biographies/chen-qigang-1951 (дата звернення : 29.07.2019).

7. Bernard Marie-Hélène. Les compositeurs chinois à l'heure de la mondialisation R-R-R : RésiderRésonner-Résister. Recherche dans les arts : présentation des travaux en cours - EHESS, Apr 2011, Paris, France. ffhalshs-00670728f. URL: https://halshs.archives-ouvertes.fr/halshs-00670728/document (дата звернення : 29.07.2019).

8. Utah Symphony. Thierry Fischer. Music Director // Five Elements. URL: https://utahsymphony.org/explore/2014/01/five-elements/ (дата звернення : 29.07.2019).

9. Qigang Chen. URL:

http://www.chenqigang.com/yueping.php?action=list\&channel_id=2 (дата звернення : 29.07.2019).

10. Qigang Chen. URL: http://www.chenqigang.com/calendar.php?channel=1 (дата звернення : 29.07.2019).

\section{References}

1. Lǐ Lánqīng. (2008). Zhongguo Zaoqi Jiaoxiang Yingue [李岗清.中国早期的交响音乐]. Early Chinese Symphonic Music. Thoughts on Contemporary Chinese Music. Beijing : Gaoden Jiao Chubanshe, 23-32 [in Chinese].

2. Lo Shii. (2003). Symphonic Genres in the Context of Chinese Musical Culture. Extended abstract of candidate's thesis. Moscow : Gnesins Russian Academy of Music [in Russian].

3. Lyan Maochun, Xiang Yugang, Li Yan. Zhongguo Yinhe Lunbian [梁茂春，项䈗刚，李岩.中国音乐论辩]

(2007). Discussions on Chinese Music. Nánchāng : Baihuachzhou wǒ zhèngzài xúnzhăo Chubanshe. [in Chinese].

4. Han Lujiao (2017). The philosophy of "Tai Chi" as a theoretical basis for the development of art in China. Extended abstract of candidate's thesis. Minsk: Belarusian State University of Culture and Arts [in Russian].

5. Qigang Chen. Biography. Retrieved from http://www.chenqigang.com/biography.php [in English, in Chinese].

6. Chen Qigang / Cdmc. Centre de documentation de la musique contemporain. Retrieved from

http://www.cdmc.asso.fr/fr/ressources/compositeurs/biographies/chen-qigang-1951 [in French].

7. Bernard Marie-Hélène (2011). Les compositeurs chinois à l'heure de la mondialisation R-R$\mathrm{R}$ : RésiderRésonner-Résister. Recherche dans les arts : présentation des travaux en cours - EHESS, Paris, France. ffhalshs-00670728f. Retrieved from https://halshs.archives-ouvertes.fr/halshs-00670728/document [in French].

8. Utah Symphony (2014). Thierry Fischer. Music Director. Five Elements. Retrieved from https://utahsymphony.org/explore/2014/01/five-elements/ [in English].

9. Qigang Chen. Retrieved from

http://www.chenqigang.com/yueping.php?action=list\&channel_id=2 [in English, in Chinese].

10. Qigang Chen. Retrieved from http://www.chenqigang.com/calendar.php?channel=1 [in English, in Chinese].

Стаття надійшла до редакиії 21.10.2019 p. 